\title{
EDITORIAL
}

\section{INNOVACIÓN UNIVERSITARIA}

Uno de los mayores desafíos contemporáneos de las universidades en América Latina es la tarea de recuperar integralmente una función que se encuentra en la génesis de este tipo de instituciones en nuestra cultura occidental: la gestión de los conocimientos sociales. La universidad, desde sus orígenes, es una institución de características muy particulares, pues combina tareas de generación, asimilación y difusión de conocimientos sociales, en un contexto de autonomía respecto de los poderes civiles, religiosos o militares, y su financiamiento se apoya en el prestigio e influencia de sus integrantes. Dicho prestigio e influencia han estado sujetos a fluctuaciones a lo largo de los siglos, pero se puede afirmar que la universidad ha sido una interfaz activa entre los conocimientos -importados, producidos o captados- de diversos orígenes y sus aplicaciones sociales en ámbitos tan diversos como la producción, el derecho, la política, las especialidades de la ingeniería y muchas otras. Sin embargo, la forma en que se transfiere o se produce la aplicación de conocimientos varía mucho más que el sentido final (o abstracto) de la actividad universitaria. La gestión disciplinaria cambia profundamente en los últimos treinta años (quizás la Bay-Dole Act de principios de los 80 en USA, marca un hito visible de dicho cambio), con la irrupción de los criterios de mercado en la actividad universitaria. En el caso de las Facultades de Ingeniería y otras especialidades de ciencias aplicadas, se trata de incorporar en su actividad habitual el desarrollo tecnológico. Ello debe hacerse de manera coherente con la forma en que la sociedad en que estamos insertos asigna los recursos que, en el caso del cambio técnico, requiere la participación de mecanismos de mercado.

En ese sentido parece necesario aclarar que no hay diferencias conceptuales entre ciencia y tecnología ni (a) en cuanto objeto disciplinario, pues aún en las disciplinas más abstractas se pueden, y, de hecho ocurre, desarrollar productos comerciales; (b) en cuanto metodología ni (c) en cuanto mérito, valor o costos de cada actividad. La diferencia entre ciencia y tecnología se entiende de manera endógena en su relación con ciertos mecanismos de mercado. La frontera entre ciencia y tecnología está dada por la potencialidad de los resultados del trabajo creativo e innovador para transarse mediante precios (por muy imperfectos que estos sean) o mediante aportes sociales basados en méritos intrínsecos al trabajo aplicado.

De esa manera, el desafío no es cambiar las funciones tradicionales de las universidades; se trata de renovar la forma en que algunos de estos se transfieren a la comunidad; es decir, producir y gestionar conocimientos con valor comercial. No se trata tampoco de agregar simplemente otra tarea a las que, históricamente, se les pudo asignar a las universidades (especialmente a las latinoamericanas). Se trata de hacerlo de manera integral y armónica pues, la tecnología no puede sustituir al desarrollo científico en sus expresiones más "puras", es decir, en sus expresiones que, desde el punto de vista económico, sólo se encuentran más alejadas del mercado. Tampoco se trata de superponer actividades alejadas de las especialidades cultivadas en cada centro de investigación, pues las ideas tecnológicas no fructifican sin una sólida base científica. Tampoco se pueden ver alejadas de funciones tradicionales en las universidades como la docencia y la extensión pues, de hecho, éstas se integran necesaria y orgánicamente con la ciencia y tecnología que las nutre. De hecho, la mayor parte de los aportes tecnológicos rupturistas surgen de investigadores jóvenes que aportan audacia y creatividad al conocimiento científico.

Se trata, nada menos, que de actualizar la definición de la labor universitaria. En una sociedad que ha cambiado profundamente, la idea de innovación salta de los textos de economía para hacernos comprender de la manera más dura que la innovación es una necesidad de supervivencia para los actores sociales, pues si un profesional, una empresa u otra institución no innova o, al menos, no actualiza sus conocimientos, otro lo hará por él y lo expulsará del mercado. Es la competencia.

El mercado competitivo de ideas tecnológicas tiene rasgos poco conocidos y, obviamente, no asimilados por las comunidades académicas. No es posible profundizar aquí este tema, pero se pueden resumir brevemente algunos aspectos que en mi experiencia resultan relevantes en las universidades de tradición latina: 
- Valoración de la investigación tecnológica competitiva. El desarrollo de innovaciones es una industria de riesgo alto. Hay mucha evidencia que muestra las dificultades de prever la rentabilidad de una nueva idea, pero quizás las fluctuaciones de mercado de las llamadas empresas tecnológicas en los últimos años sea la evidencia más contundente de dicha dificultad. No sólo el problema de predictibilidad de los resultados aparece como recurrente, hay también mucha evidencia que hace pensar que la innovación de mayor complejidad se desplaza hacia las universidades y otros centros de investigación de alta complejidad.

- $\quad$ Publicar o patentar. En algún sentido incompatible, pues la actividad científica se orienta al juicio de pares y ello se hace mediante la publicación de trabajos. Por otra parte, la innovación requiere, como su nombre lo indica, novedad, de modo que no es patentable ni apropiable el conocimiento público. Esta disyuntiva obliga a decidir tempranamente el sentido de los proyectos de investigación. Ello no es tarea sencilla si se considera el punto anterior.

- Las múltiples soluciones de problemas comunes. El impulso del desarrollo tecnológico es la necesidad solvente (de mercado), de manera que es normal observar proyectos de investigación tecnológica muy diferentes (disciplinaria o metodológicamente) que pretendan resolver los mismos problemas. Lo anterior produce explicable ansiedad y competencia entre investigadores y, simultáneamente, confusión en los responsables de la gestión de recursos universitarios.

- $\quad$ La complejidad del trabajo en equipo. El desarrollo tecnológico moderno es, crecientemente, resultado de trabajo de equipos multidisciplinarios, dispersos entre una gran variedad de instituciones o países, y que involucran actores institucionales que operan con lógicas distintas (empresas, gobierno y universidades). Aparece, por tanto, la necesidad de nuevas formas de contratación y asociación, la obligatoriedad de la trazabilidad de los procesos productivos de innovación y la disponibilidad de recursos de uso común (administración, soporte legal y otros), que resultan imprescindibles para el reparto de beneficios de la investigación aplicada.

Fernando Cabrales Gómez

Director Regional

Corfo Región de Arica y Parinacota

Dirección: 7 de junio 268, piso 7

Arica, Chile

fcabrales@corfo.cl 